\title{
REWOLUCJA OCZAMI WANDEI
}

Reynald Secher, Ludobójstwo francusko-francuskie. Wandea - Departament Zemsty, Wydawnictwo Aletheia, Warszawa 2015

\section{REVOLUTION SEEN THROUGH THE EYES OF VENDÉE}

\section{Abstract}

This paper aims at reviewing a publication entitled The Franco-French Genocide. Vendée - the Department of Vengeance by Reynald Secher. The book touches on the issue of fights between the Republicans and peasants opposing the regime of the revolutionaries. This event's history has been hushed up. Moreover, it has effectively been removed from the national narrative. Reynald Secher propagates the process of reminding us of those facts. In this review, information on the fights will be contrasted with theories presented by other historians in order to make the reader aware of the whole process's complexity and of many persistent inaccuracies.

Materials collected by the author will be subjected to our analysis. Due to the reconstruction of events by eye-witnesses, previously an underestimated but abundant source of knowledge, the author has learned the truth about the acts of the revolutionary heroes. In Secher's work, the accuracy with which he presents all the issues becomes equally important.

Special attention should be paid to the very word "genocide" and its associations. Indeed, the work is

JOANNA STĘPNIEWSKA Uniwersytet SWPS, Warszawa E-mail: as.stepniewska@gmail.com https://orcid.org/0000-0002-4839-0787

CITATION: Stępniewska, J. (2019). Rewolucja oczami Wandei. Sprawy Narodowościowe. Seria nowa, 2019(51). https://doi.org/10.11649/sn.1825

This work was supported by the author's own resources. No competing interests have been declared.

This is an Open Access article distributed under the terms of the Creative Commons Attribution 3.0 PL License (creativecommons.org/licenses/by/3.0/pl/), which permits redistribution, commercial and non-commercial, provided that the article is properly cited. (C) The Author(s) 2019

Publisher: Institute of Slavic Studies, Polish Academy of Sciences 
not focused on carnage. Instead, it plays a part both as a reminder that carnage did take place, and a presentation of reasons for its occurrence.

Key words: France; Vendée; revolution; genocide; freedom; equality; brotherhood; republic

\section{Streszczenie}

Niniejsza praca ma na celu zrecenzowanie publikacji Ludobójstwo francusko-francuskie. Wandea - Departament Zemsty Reynalda Sechera. Książka dotyczy walk między republikanami i chłopami sprzeciwiającymi się rządom rewolucjonistów. Historia o tym zdarzeniu została wyciszona i skutecznie usunięta z narracji narodowej. Reynald Secher propaguje proces „odpamiętnienia” tamtejszych wydarzeń. W niniejszej recenzji informacje na temat walk zostaną skontrastowane z teoriami prezentowanymi przez innych historyków, aby uświadomić czytelnikowi złożoność całego procesu oraz wiele wciąż istniejących nieścisłości.

Analizie poddane zostaną zebrane przez autora materiały. Dzięki rekonstrukcji zdarzeń oczami bezpośrednich świadków wydarzeń, dotąd niedoceniona skarbnica wiedzy, autor poznat prawde o czynach bohaterów rewolucji. W pracy Sechera równie ważna staje się szczegółowość, z jaką przedstawia wszystkie elementy.

Szczególną uwagę należy przyłożyć do samego słowa „ludobójstwo" i konotacji z nim związanych. Sednem pracy nie jest bowiem przedstawienie rzezi, ale przypomnienie, że miała ona miejsce, i zaprezentowanie powodów jej zaistnienia.

Słowa kI uczowe: Francja; Wandea; rewolucja; ludobójstwo; wolność; równość; braterstwo; republika

W iedza o zdarzeniach w Wandei wydaje się dobrze utrwalona w historii Europy i Francji. Okazuje się jednak, że to, co znane wszystkim, kryje jedną z największych tajemnic.

Wandea, tak szczegółowo opisywana przez Reynalda Sechera w recenzowanej książce, to kraina historyczna oraz departament wydzielony w zachodniej Francji, obszarze o nazwie Poitou. Dzisiaj dawny teren Wandei to jeden z pięciu departamentów, wchodzący w skład regionu administracyjnego w zachodniej Francji - Kraj Loary.

Sama Wandea zyskała sławe przez burzliwe wydarzenia, które miały tam miejsce w okresie rewolucji francuskiej. Zmiany, które dość brutalnie zostały wprowadzone przez ówczesny, nowo powstały rząd, doprowadziły do powstania chłopskiego nazwanego później wojnami wandejskimi. Chłopi stanęli w obronie religii, sprzeciwiając się potędze nowej władzy, co skończyło się ich klęską 23 grudnia 1793 roku. Wojska republiki pod dowództwem generała Turreau ruszyły do dalszej walki, mimo już uzyskanego zwycięstwa. Postanowiono zniszczyć wszystkich na swojej drodze, aby ostatecznie spacyfikować Wandee i nie dopuścić do ponownych zamieszek. W wyniku likwidacji kontrrewolucjonistów, jak nazwano ich w Paryżu, śmierć poniosło ponad 150 tysięcy ludzi, w tym kobiet i dzieci. "Nie ma już Wandei” - mówili generałowie. Nie próbowano ułagodzić konfliktu ani dojść z kontrrewolucjonistami do porozumienia. Użyto siły zamiast słów, później „zakopując" historię Wandei i na wiele lat o niej zapominając. 
Reynald Secher próbuje odkryć prawdę, która kryje się za pięknymi hasłami o równości, miłości i braterstwie. „Wolność, Braterstwo, Równość albo Śmierć”, mówił generał Turreau, głównodowodzący w czasie konfliktu z Wandeą. Autor decyduje się na ujawnienie wszystkich grzechów epoki rewolucji oraz grzechów własnego kraju. Owa zapomniana na długo historia przypomina liczne, równie niechlubne zdarzenia z dziejów każdego z krajów i jak w wielu innych przypadkach władza nie zawsze przychylnie patrzy na ponowne ich odkrywanie. Opublikowane przez niego informacje spotkały się z krytyką i wystąpil otwarty konflikt. Secher stracił pracę, nie chciano z nim przeprowadzać wywiadów ani współpracować. W odpowiedzi badacz założył własne wydawnictwo, w którym publikuje teksty ujawniające prawdę. Pisarz od ponad 30 lat zajmuje się sprawą Wandei, odrzucając opinie niektórych historyków, prezentowane w przedmowie do książki, dowodzące jakoby termin ludobójstwo „nie stosuje się do wydarzeń zachodzących wewnątrz danej wspólnoty politycznej i narodowej" (Secher, 2015, s. 17).

Podczas gdy samą rewolucję datuje się na lata 1789-1799, autor swoją historię rozpoczyna na samym początku XVIII wieku. Mocno zarysowuje geneze zdarzeń, twierdząc że bierze ona swój początek w trudnej sytuacji politycznej, społecznej oraz gospodarczej, gdzie niemały wpływ na losy historii miał system feudalny. Opłaty, podatki na rzecz króla i przymusowe pobory do milicji musiały w końcu prowadzić do konfliktu lub otwartej walki. Każdy kolejny akapit i każda strona wzmacnia napięcie, a czytelnik biernie czeka, kiedy wybuch nastąpi. Jako krok następny, kiedy rozbrzmiewają już, choć ciche jeszcze, pierwsze odgłosy rewolucji, drobiazgowo przedstawione zostają zmiany, które zachodziły w tytułowym rejonie Francji. Czytelnik wciąż czeka na znaną sobie krwawą potyczkę, gilotyny, uliczne walki i równie popularne uliczne egzekucje. Wreszcie, niczym pierwsze przebłyski burzy, dociera do początków rewolucji i następujących po niej pierwszych konfliktów już republikanów z niższymi klasami.

Pierwszy rozdział publikacji skupia się wyłącznie na przedstawieniu szczegółowego obrazu przed przemianami, a więc i na skrupulatnej prezentacji kluczowych powodów rozpoczęcia rewolucji społecznej i późniejszych zamieszek. Nie została pominięta analiza systemu feudalnego, panującego w ówczesnej Francji, w której najcięższymi zobowiązaniami finansowymi wobec państwa obarczano stan chłopstwa i mieszczaństwa. Doskonale odwzorowuje to stynna satyra Chłop niosący na swych barkach księdza i szlachcica. To ich podatki, dziesięciny, opłaty i pobory zapewniały przetrwanie i niemałe zyski innym, mniej licznym klasom. Poddawanie ludności zbyt silnym naciskom ze strony władzy lub innej, mniej licznej części społeczeństwa zawsze w historii Europy doprowadzała do konfliktów. To jednak według Sechera nie stanowiło głównego powodu wszczęcia kontrrewolucji.

Do eksplozji dochodzi, kiedy władze postanowiły wtrącić się w sprawy administracji kościelnej. Ponieważ Wandea była obszarem zacofanym, który zamieszkiwała głównie ludność wiejska, religia organizowała ich życie, stając się jedną z ważniejszych jego części. Republikanie rozkazali osobom duchownym składać przysięgę na konstytucję cywilną, co spotkało się z negacją wśród kleru w Wandei. To prowadziło do ich wysiedleń, grzywny oraz ograniczenia wolności. Władze gminne jednogłośnie poparły republikanów w ich działaniu, co skutecznie zniszczyło zaufanie mieszkańców. Wyrzekając się każdej władzy państwowej oraz będąc jednocześnie zmęczonym bezsilnością wobec narzuconych rozkazów administracji, zdecydowali się na otwartą walkę.

Poprzez dogtębną analizę wszystkich zmian społecznych i politycznych w pierwszej części publikacji autor podaje powody wzburzenia obywateli, uwzględniając wszystkie klasy. Skupia się jednak szczególnie na niższych warstwach społecznych i duchowień- 
stwie, co prowadzi do zubożenia obrazu rewolucji, który tak skrupulatnie stara się tworzyć. Kolejne nici budują skomplikowaną sieć, a w tym przypadku brakuje tych, możliwe że mniej ważnych, mówiących o atmosferze w klasach wyższych opisywanej miejscowości, a przecież znane są już informacje o szlachcicach, którzy prowadzili armię stworzoną z miejscowych chłopów. Powstają dwa fronty: republikanie stojący u władzy i mieszkańcy Wandei sprzeciwiający się nowym rządom.

Jednocześnie, zaniedbując jedną klasę, autor szczegółowo opisuje losy innej. Silnie wyodrębniona przez niego została historia duchowieństwa we Francji, głównie w Wandei. Powodem może być potraktowanie ich losów jako przyczyny wybuchu samej kontrrewolucji. Tutaj również zabrakło głębszej analizy sytuacji sprzed rewolucji, kiedy duchowieństwo postanowiło pobierać wysokie podatki od ludności niższej klasy. Wyjątkowo jednak obszernie, co stanowi atut pracy, potraktowano niesprawiedliwe, a może nawet krzywdzące i graniczące z dyskryminacją działania władzy wobec księży. Narzucono na nich ograniczające przepisy, zmuszono do składania przysięgi i spętano sferę sacrum regułami władzy administracyjnej. Marek Wąsowicz w publikacji Między tronem, giełdą i barykadą wspomina o niechęci opinii publicznej i rządu wobec Kościoła. Przetacza słowa poety Heinricha Heinego: „Większość Francuzów nie chce więcej słyszeć o tym trupie i chwyta za chusteczkę, by zatkać nos, gdy mowa o Kościele" (Wąsowicz, 1994, s. 126). Podczas gdy Wąsowicz opisuje skrajnie negatywny stosunek do Kościoła, radość z jego upadku oraz wrogość wobec kleru, Secher skupia się jedynie na brutalności rządu, sugerując, że opinia publiczna w Wandei nie zgadzała się z poczynaniami władz i starała się swoich księży chronić przed atakami, wspierając przedstawicieli Kościoła. Czy to znaczy, że sytuacja Wandei była odmienna od tej panującej wśród ludności reszty kraju a może opinia o Kościele nie była aż tak zła i obywatele nie pałali aż tak wielką niechęcią względem władzy kościelnej? Nie wiadomo. Kolejny raz brakuje odniesienia do reszty kraju i wyjaśnienia.

Sam opis sytuacji duchownych mieszkających w Wandei w publikacji Sechera charakteryzuje się szczegółowością i wnikliwością. Krzywdzące traktowanie duchowieństwa spotkało się z odzewem, negacjami, ucieczkami lokalnych duszpasterzy a na koniec wszczęciem rewolty. To właśnie usunięcie starych, znanych księży i wprowadzanie do parafii księży nowych, nieznanych i zbyt przychylnych administracji, a jednocześnie zbyt mocno korzystający z własnej władzy, stało się jednym z głównych powodów walk, które miały miejsce w osławionej już Wandei - tak przynajmniej wynika z tekstu Reynalda Sechera. Późniejsze informacje na temat poboru oraz administracji dla czytelnika stanowią sytuacje generujące w rzeczywistości dużo mniejszy konflikt między rządzącymi a ludnością Wandei. Czy w istocie były to rzeczy mniejszej wagi? Na podstawie słów Jana Baszkiewicza, jakoby „Chłopi w Wandei odpowiedzieli na pobór powstaniem, które rychło postarają się wyzyskać arystokraci i rojaliści" (Baszkiewicz, 1974, s. 434), można wyciągnąć zgoła odmienne wnioski. Oznacza to bowiem, że prawdziwe, główne powody buntu mogły być inne. Z tekstu Sechera wynika, że to tylko kolejne utrudnienia prowadzące do nieporozumień wśród już zdenerwowanych obywateli, a nie istotne kwestie. Świadczy też o tym zakres opisanych danych i sytuacji, brak takiej szczegółowości, z jaką spotykamy się czytając o dyskryminacji księży. Aczkolwiek nie wiem, czy sam autor pragnął, aby czytelnik do takich właśnie doszedł wniosków. Moim zdaniem inne zdarzenia poza dyskryminacją duchownych stanowiły równie ważny element opisywanego przez Sechera konfliktu, a więc powinny zostać w niniejszy pracy opisane bardziej szczegółowo. Jan Baszkiewicz sugeruje, że to właśnie pobory stały się jednym z głównych powodów powstania chłopstwa. Andrzej Zahorski potwierdza tę teorię, twierdząc, że „bezpośrednią jego (wy- 
buchu powstania w Wandei - dopis.J.S.) przyczynę stanowiło brutalne przeprowadzenie nowego poboru, który zarządziła Konwencja 24 lutego 1793 roku" (Zahorski, 1964, s. 81). Autorzy nacisk kładą na zupełnie inne zdarzenia. Brak zgody i nieścisłości między autorami omawiającymi ten sam temat nie jest niczym nowym ani szczególnym w nauce. Możliwe, że Reynald Secher ma rację, że w samej Wandei pobory to zdarzenia mniej istotne i z tego wynika potraktowanie ich przez pisarza w tak ogólny sposób.

Autor zapomniał lub celowo zaniedbał pełen opis wydarzeń oraz konfliktów ówczesnej Francji. Prawdą jest, że podatki w czasach przedrewolucyjnych były wyjątkowo wysokie i obarczono nimi głównie najniższą klasę. Zabrakło jednak wyjaśnienia, dlaczego rząd postanowił narzucić na obywateli tak duże zobowiązania finansowe względem kraju. Jan Baszkiewicz w Historii Francji wyjaśnia, że wojna amerykańska „kosztowała Francję 2 mld liwrów" (Baszkiewicz, 1974, s. 394), co skutkowało zubożeniem skarbu państwa. Dodatkowo, ówczesny minister Calonne rządzący finansami postanowił państwowymi pieniędzmi spłacić swoje prywatne długi. To wszystko doprowadziło do wprowadzenia nowych podatków, m.in. gruntowego. Choć Calonne starał się zjednać sobie trzeci stan powołując zgromadzenia lokalne z cenzusem wyborczym, zmuszenie ich do zbyt wysokich płac okazało się mocniejszym bodźcem, który wywoływał niechęć wobec klasy rządzącej. Inne warstwy społeczne również nie okazały się zadowolone dzieleniem władzy z niższymi stanem: „Kler niechętnie przyjął projekt dopuszczenia chłopów do wykupu ich praw feudalnych" (Baszkiewicz, 1974, s. 395). Nastroju nie poprawiły podatki narzucone na szlachtę i księży. Również Andrzej Zahorski w publikacji Paryż lat rewolucji i Napoleona twierdzi, że „Bezpośrednim powodem wybuchu rewolucji stał się krach finansów państwa, wywołany wadliwym systemem podatkowym (duchowni i szlachta nie płacili podatków), rozrzutnością dworu, długami zaciągniętymi jeszcze w związku z dawnymi wojnami" (Zahorski, 1964, s. 35). Bankructwo państwa stanowiło ważny element wyjaśniający sprzeciw ludu wobec władzy i dalsze losy rewolucji, może nawet ważniejszy niż sytuacja duchowieństwa po rewolucji. Brak więc wyjaśnienia, co tak naprawdę było główną przyczyną wybuchu powstania.

Przedstawione powody rewolucji są wyłącznie wewnętrzne, a czasami nawet wyjątkowo lokalne. Brak w publikacji akapitu dotyczącego zewnętrznych wpływów innych krajów lub zmian, które zachodzą w skali europejskiej, a które mogłyby stać się kluczowe w obliczu zdarzeń XVIII-wiecznej Francji. Nie ma słowa na temat zewnętrznych walk, które przecież toczyła w tym czasie Francja również z sąsiadami z samej Europy. Francja zaczęła ponosić klęski na frontach w walce z Anglią, Hiszpanią i Holandią, a wojny musiały wpłynąć społecznie, finansowo i gospodarczo na każdego obywatela. Wandea nie była wyspą szczelnie odizolowaną od reszty Francji, więc i do niej musiały docierać głosy z zewnątrz.

O ile w każdej publikacji dotyczącej rewolucji francuskiej znajdą się informacje o genezie całego konfliktu, powodach wybuchu owych zamieszek i wszczęcia tak ważnej w historii Europy rewolty, o tyle w omawianej publikacji odczuwam niedosyt tego typu informacji. Autor, słusznie z resztą, skupił się na losach Wandei, więc sytuacja w Paryżu nie musiała być opisywana. Skoro jednak rewolucja dosięgnęła Wandee, należało w jakiś sposób wprowadzić czytelnika w sprawy polityczne całego kraju, a nie poprzestać tylko na historiach danego obszaru, historiach osadzonych zbyt lokalnie, aby wyjaśnić całą skomplikowaną sieć powiązań z owego burzliwego okresu.

Po przygotowaniach do właściwych zdarzeń odbywających się w Wandei, uwzględnionych na około 150 stronach, czytelnik wreszcie dowiaduje się, jak wyglądało ludobójstwo, które miało tam miejsce. "Wandea musi stać się narodowym cmentarzem!" - krzyczał 
Turreau i tak też się stało. Gniew generała wynikał z udanych akcji partyzanckich lokalnych chłopów, którzy wykorzystując warunki terenowe mogli podejmować skuteczne akcje przeciw wojsku. Dowodzeni przez szlachciców, takich jak François-Athanase de Charette (zwany Królem Wandei) oraz Henri du Vergier de la Rochejaquelein, zdobywali niekiedy po potyczce, choć na krótko, duże miasta. „Wojujący z Wandeą sankiuloccy generałowie (Santerre, Ronsin) nie odnosili sukcesów" (Baszkiewicz, 1974, s. 438). Uznali, że ukaranie Wandei będzie jedynym stosownym wyjściem. Rewolucja, mająca na celu dbać o lud, silną ręką zmuszała go do posłuszeństwa i wykonywania poleceń. Obywatelom miasta obcinano głowy, a kiedy to okazało się zbyt powolną i pracochłonną metodą, zaczęto ich topić i rozstrzeliwać. Krwawa walka zaczyna przyćmiewać idylliczny obraz wolności na barykadach, którym szczyci się historia Francji. „Konwent Narodowy, wspaniałomyślny jak lud, który reprezentuje, zapomina o przeszłości i wybaczy", głosi fragment wypowiedzi przywódców rewolucji przetaczanego przez autora, a mimo to rzezie nie ustały. Obietnice uwolnienia i zjednoczenia spełzły na niczym. Tym prawdopodobnie była właśnie rewolucja pod płaszczykiem pięknych haseł i idyllicznych wizji. Ta wizja, która w dużej mierze trwa do dziś, została sprawnie rozmyta przez fakty, które autor z taką pieczołowitością wyszukiwał w archiwach, dokumentacjach, prywatnych i publicznych listach oraz zapiskach.

O ile historia Wandei została opisana pieczołowicie, skupiając się na każdym szczególe genezy konfliktu, rozwoju przebiegu wydarzeń i na jej zakończeniu, o tyle zabrakło w pracy szerszej perspektywy. Czytelnik zdaje sobie sprawę, w jakich ramach dzieje się cała historia oraz jaki los wtedy spotkał całą Francję, ale autor ówczesną historię kraju traktuje zbyt ogólnie. Do pełnego obrazu potrzeba jeszcze kontekstu, kilku akapitów, które odnosityby się do przebiegu rewolucji w kraju. Kontrast między tym, co działo się w innych miastach, a tym, co spotkało ludzi z Wandei, mógtby okazać się doskonałym dopełnieniem. Przy braku tego porównania oraz wstawienia jedynie fragmentu dziejów całego kraju, to jak opowieść, która zaczyna się w środku i nie doczekuje prawdziwego zakończenia. Wandea wydaje się samotną wyspą oderwaną od świata zewnętrznego, a to przecież świat zewnętrzny, zarówno sama Francja jak i inne Europejskie kraje, które musiały przecież wpłynąć na taki a nie inny rozwój wypadków, spowodowały, że to miasto spotkało takie nieszczęście.

Atutem opisywanej przeze mnie pracy, jak powtarzam, są zdobyte $w$ archiwach, bibliotekach i urzędach materiały. Wielkie gratulacje należą się autorowi, ponieważ, jak wiadomo, wiele dokumentów zostało zniszczonych jeszcze w czasie rewolucji. Oznacza to, że szukać trzeba w zbiorach nietypowych, omijać dokumentację miasta, a decydować się na listy, pamiętniki, wspomnienia. Okazuje się więc, że stosunkowo mało można w owej publikacji znaleźć materiałów oficjalnych, państwowych. Do tak wielkiego zbioru z pewnością przyda się obecne w przypisach objaśnienie, w których autor podaje miejsce, z którego informacja została zaczerpnięta. Moim zdaniem można by pójść nawet o krok dalej i wymienić adresy poszczególnych instytucji, dzięki czemu głodni wiedzy, wstępnie już zainteresowani odbiorcy, będą mogli samodzielnie odbyć tę samą lub podobną drogę co autor.

Mimo dużej szczegółowości materiału, Czytelnik nie gubi się w natłoku informacji ani nie musi „skakać” po rozdziałach, aby skleić cały obraz przeszłości, który roztacza przed nim autor. Nie da się zaprzeczyć, że to wielki atut omawianej pracy. Bogaty zbiór dokumentacji, map, listów i notatek zebranych w różnych archiwach wzbogaca opowiadaną już wielokrotnie historię i pogłębia ją o szczegóły, o których nikt nie wiedział lub o których mówić nie chciano (lub nie było wolno). Dowodzi to jednocześnie potężnej pracy i zaangażowania autora, aby odkryć prawdę pod mitami i powszechną narracją nie zawsze zgodną 
z prawdziwymi losami rewolucji. Nie od dziś bowiem wiadomo, że każdy naród w swojej historii ma momenty mniej chwalebne, chce je ukryć, zamaskować, przemilczeć lub zmanipulować fakty po to, aby nie rozdrapywać ran. W ten sposób piszą poprawioną wersję historii i wybielają się nie tylko w oczach przedstawicieli innych narodów, ale również, lub nawet przede wszystkim, w swoich własnych. Reynald Secher stara się odsunąć zasłonę milczenia, aby odkryć prawdę, fakty mniej znane lub mniej dostępne.

Choć teksty źródłowe są nader interesujące i uzupełniają losy Francji z czasów jeszcze przed rewolucją, czynią pierwszą część zbyt długą, a więc i nieco męczącą. Wstęp wydaje się obarczony zbyt wieloma detalami oraz cytatami. Oznacza to oczywiście, że publikacja zawiera bogaty zbiór istotnych dla rozwoju historii informacji, ale zbyt bogaty zbiór może sprawiać wrażenie przesytu. Nadmierna szczegółowość grozi bowiem utratą wątku lub odejściem od kluczowego tematu. Jednocześnie skupienie się na najmniejszych detalach sprawia, że zabrakło miejsca na szersze spojrzenie i przedstawienie ogólnego obrazu sytuacji Wandei. Autor przemyka od nadmiernej szczegółowości do zbytniego uogólnienia. Raz przedstawia obraz milicji w Poitou na kilku stronach, a raz zbywa czytelnika kilkoma zdaniami i liczbami. Zamiast nakreślić obraz zdarzeń w akapicie bądź dwóch, pojawiają się liczne, szerokie opisy wypełnione nazbyt, moim zdaniem, szczegółowymi danymi.

Mimo że praca jest obszerna, nie stanowi wielkiego wyzwania dla czytelnika. Oferuje przyjemną lekturę nawet dla tych, którzy historią Francji interesują się mniej. Jednocześnie podzielenie materiału na rozdziały i później na podrozdziały okazuje się w tym wypadku rozwiązaniem idealnym, ponieważ zapewnia to wypunktowanie bogatego zbioru danych i przedstawia treści czytelne dla odbiorcy. Ponieważ pracy naukowej zwykle nie czyta się niczym beletrystyki, w całości strona po stronie, zaciekawiony odbiorca może łatwo znaleźć te informacje, które najbardziej są mu potrzebne lub najbardziej okażą się dla niego interesujące. Bez problemu również wróci do tych części książki, które wydawały mu się najciekawsze.

Czytelnik przed rozpoczęciem pierwszego rozdziału powinien dobrze przestudiować administracyjną i historyczną mapę Francji. Okazuje się bowiem, że autor nie wyjaśnia, czym dokładnie jest Wandea. Nieposiadający dostatecznej wiedzy czytelnik mógłby z łatwością uznać to za jedno z miast francuskich. To mogłoby w pierwszym rozdziale prowadzić do nieścisłości. Zbyt szeroki opis Poitou i zbyt mało odniesień do samej Wandei powoduje, że początek drugiego rozdziału staje się niedopasowany, niczym element układanki, którego krawędzie nie składają się idealnie na pełen obraz. Czytelnik może poczuć się zagubiony, dlaczego opis dotyczy Poitou, a później przechodzimy od razu do Wandei. Większa ilość danych z Wandei i ograniczenie informacji z Poitou mogłoby ten dysonans zmniejszyć. Wystarczyłoby poświęcenie jednego akapitu na pierwszych stronach książki wyjaśniającego, że Wandea jest departamentem w zachodniej Francji, zajmującym zachodnią część Poitou, krainy historyczneji.

Jeśli czytelnik ma nadzieje, że odnajdzie w pracy naukowej Reynalda Sechera pikantne fragmenty pełne przemocy rewolucyjnej, mocno się zawiedzie. Poza kilkoma opisami tortur, jakim poddawano obywateli (topienie, wieszanie, wyrywanie kończyn), nie należy obawiać się drastycznych akapitów. Mimo że książka dotyczy ludobójstwa, autor skupia się na szerszej historii łącznie ze źródłem problemu, a nie na opowieściach rodem z nowoczesnych horrorów produkcji Hollywoodu. Autor pragnął pokazać fakty nieznane, ukrywane i zatajane, które nie zawsze skupiając się na morderstwach, gwałtach oraz torturach. Choć, oczywiście, właśnie do tego ostatecznie prowadziły.

Każda zmiana niesie ze sobą ofiary. O wielu jeszcze z pewnością nie wiemy... 


\section{BIBLIOGRAFIA}

Baszkiewicz, J. (1974). Historia Francji. Wrocław: Zakłady Narodowe imienia Ossolińskich - Wydawnictwo.

Secher, R. (2015). Ludobójstwo francusko-francuskie: Wandea - Departament Zemsty (M. Miszalski, Tłum.). Warszawa: Wydawnictwo Aletheia.

Wąsowicz, M. (1994). Między tronem, giełdą i barykadą. Warszawa: Wydawnictwo Omnia.

Zahorski, A. (1964). Paryż lat rewolucji i Napoleona. Warszawa: Wiedza Powszechna. 